\title{
Amplifying Citizens' Voices in the Face of Media Globalization
}

\author{
Carmen Echazarreta Soler ${ }^{1}$, Albert Costa Marcé ${ }^{1}$
}

${ }^{1} \mathrm{PhD}$, Universitat de Girona, Spain

${ }^{2} \mathrm{PdD}$ Student, Universitat de Girona, Spain

Correspondence:

Carmen Echazarreta Soler: carmen.echazarreta@udg.edu \& Albert Costa Marcé: albert.costa@udg.edu

Universitat de Girona, St. Domènec. Pl. Ferrater Mora, 1, Office 518, 17071 Girona, Spain.

\author{
Received: February 6, 2018 \\ Accepted: March 6, 2018 \\ Online Published: April 23, 2018 \\ doi:10.5539/ibr.v11n5p135 \\ URL: https://doi.org/10.5539/ibr.v11n5p135
}

\begin{abstract}
Economic crises have mainly affected the more vulnerable social sectors and created losses of freedom and inequality. Currently, most media are controlled by a relatively small group of companies around the world. In the face of this situation, networked society has accelerated the development of alternative communication models, which act as loudspeakers for citizens' voices. The aim of this study is to describe the main features of the new forms of citizen expression, communication and cooperation, such as social networks, review sites, citizen journalism and the collaborative economy. It is concluded that in the face of these new challenges it is essential to continue to develop ethical principles of self-regulation to ensure the accuracy and thoroughness of new forms of communication on the Net.
\end{abstract}

Keywords: communication, social networks, review sites, citizen journalism and ethical principles for self-regulation

\section{Introduction}

In the current environment, the economic crisis has fundamentally affected the most vulnerable social sectors, generating unemployment and job insecurity. In addition, there have been losses of freedom, inequality and exclusion at all levels.

With regard to the media, although historically they had represented a resource for citizens against the abuse of powers, most media are now controlled by a relatively small group of global companies with a significant weight in the world's economy. These companies control media groups and often act as the ideological arm of globalization, diminishing popular demands, preventing changes to the social hierarchy and maintaining inequality in the distribution of wealth (Ramonet, 2016).

According to Herman and Chomsky (2010), one of the indicators for evaluating democracy in a State is the freedom of its media. In respect of this, the United Nations states: "Freedom of information is a fundamental right and [...] the cornerstone of all freedoms".

Therefore, in the current era of vulnerability, in which part of society is at the risk of exclusion, the media should make an effort to reconcile social profitability with economic efficiency and: a) Promote values such as freedom, equality, justice and ideological pluralism; b) Foster full respect for minorities through democratic debate, free, pluralistic, and objective information and freedom of expression; c) Implement actions to promote the rights of minors, equality between the sexes and non-discrimination; d) Offer content which is of high quality, innovative, diverse and ethically rigorous; and e) Ensure consumer rights are protected (Manfredi, 2004).

The globalization of the economy has undermined the power exercised by the media to defend people's fundamental right to be informed and the need for pluralistic and rigorous journalism. In this setting, organizations such as the IMF and the World Bank influence large economic events, protect governments and dictate the trends of the economy. In contrast to this, and acting as a vehicle that amplifies the voices of citizens, this article analyzes social networks, review websites, citizen journalism, the collaborative economy and ethical principles of self-regulation, opportunities which have been generated to guarantee individuals' right to inform and be informed. 


\section{Method}

\subsection{Social Networks. Citizens' Voices Go Viral}

The exponential growth in social networks has set alarm bells ringing in the traditional media and they have come to be considered the main sources of entertainment and information, able to incorporate elements, resources and characteristics of the traditional media alongside new elements such as interactivity, videogames, audiovisual content and virtual reality, as well as offering an economically more austere cost model. According to Campos (2008), although the traditional media have the advantage of being more information- than entertainment-oriented, it requires an effort for them to regenerate themselves in the current media landscape.

In April 2016, Facebook had 1,650 million active users worldwide, of whom 934 million entered Facebook on a daily basis; 22 million were based in Spain. In July of the same year, Twitter had 310 million active monthly users, of whom 1.5 million were Spanish. According to García-Galera, Del Hoyo-Hurtado, and Fernández-Muñoz (2014) social networks are increasingly used to actively claim a space for citizens' voices.

In Spain, a profound transformation is taking place whereby journalism and the traditional media are moving progressively towards some Spanish cybermedia on social networks such as Facebook to locate and develop new journalistic products. However, results show that the majority do not take advantage of the Net to encourage participation, leading to the conclusion that spaces and resources are not optimized (Vivo, 2010).

Recent studies suggest that more than $95 \%$ of British university students think Facebook is more useful for socializing and talking with friends about work than actually doing work. They also believe that it is not a network used for purposes related to formal education, although it is sometimes used informally for the purpose of learning (Madge, Meek, Wellens, \& Hooley, 2009).

Given their enormous influence, companies are now being forced to integrate social networks into their communication and marketing strategies. We analyzed Facebook and Twitter use by the three main commercial brands in 15 different sectors in Spain in order to offer an overview of and analyze the activity of those accounts most sensitive to criticism and identify and assess the communication strategy implemented by their respective managers. After analyzing 5,433 tweets and 3,000 posts, we were able to verify the companies' massive presence on social networks as well as companies' increasingly widespread use of them to communicate with their customers (Dasilva, 2013).

The results of an investigation by Aced Toledano and Lalueza Bosch (2016) showed that, general speaking, there is no significant difference between the use of social media by American and Spanish companies. A statistically significant difference is observed in customer service via Twitter, which is more widespread among IBEX 35 than Fortune 500 companies. A further significant difference is that IBEX 35 companies publish more audiovisual content in blogs and receive twice as many likes on Facebook as Fortune 500 companies. In both cases, there is a strategic use of social media by professionals from both countries. In fact, according to the results of the investigations by Islas, Arribas, Piscitelli, Adaime, and Binder (2010), companies must make an effort to "Understand social networks as media environments" as it is observed that citizens make an exponential use of social networks to report business malpractice.

A recent study on Starbucks by Chua and Banerjee (2013a) exhaustively analyzed the chain's communication in newspapers, magazines, articles, books and social networks, emphasizing the extent to which the latter means of on-line communication can help obtain more knowledge about customers so as to better manage their needs. The study concludes that, due to their interactivity characteristics, social networks are the best means of finding out more about consumers and managing the organization's online reputation. Starbucks is redefining customer relations, going from being passive recipients to key active collaborators in the company's innovation. Finally, the company also uses social networks to build customer loyalty.

\subsection{Review Websites. Users who Share Their Experience on the Net}

A study conducted by the ITB-Berlin (2014), which analyzed data from a survey of around a thousand Internet users who had reviewed 17 pages of comments, revealed that $96 \%$ of travelers consult review websites and $82 \%$ trust published opinions. Furthermore, $30 \%$ think that a high percentage of criticisms are false, while website managers stated that fake reviews make up between $1 \%$ and $5 \%$ of the total. To evaluate the authenticity of comments, users rated the content that seemed genuine, and statistically $70 \%$ stated that the establishment was as good as the comments indicated, while $20 \%$ described it as even better. In the same study, 1,500 questionnaires were administered to hotel managers. The results indicated that $94 \%$ thought review websites have a great influence on consumers when choosing accommodation, while $81 \%$ believed comments had a direct impact on the image of the hotel. 
With 350 million unique visitors per month and over 320 million reviews and comments, Tripadvisor was considered the largest travel website in the world in 2016. According to Horner and Swarbrooke (2016), the site has introduced a series of interesting developments that have made a significant contribution to the Net: An accreditation program for hotels and their environmental policies, called Green Leaders; A travel forum where travelers can pose questions and other travelers can post responses; Apps for smartphones and tablets that make it easier to consult information during a trip; A link to Facebook that makes it easy for our friends to see what content we have been reviewing on Tripadvisor; and its own awards for, among others, hotels, destinations, and tourist attractions.

In light of the growth in content generated on the Internet, research carried out by Chua and Banerjee (2013b) focused on analyzing the reliability of reviews appearing on TripAdvisor. The results suggested that such reviews could largely be considered reliable.

In contrast, according to Cánovas, García, and María-Dolores (2015), the reliability of the more than 170 million reviews published on the site is continuously questioned. Although TripAdvisor or Booking.com advise establishments to encourage customers to participate by giving their opinion, they explicitly prohibit anything being offered in return. The study detects a significant number of cases where draws are held, observing that these condition participants by biasing their responses towards positive scores.

Furthermore, a study carried out by Tuominen (2011) on 1,752 opinions of 77 hotels in 6 different cities concluded that there is a correlation between the average ratings awarded to hotels and the number of ratings obtained. It is suggested that previous opinions of other users influence subsequent ones. Although many consumers consult online reviews before booking trips, research on the impact of user ratings and comments on tourist accommodation is insufficient. The results showed a positive correlation between the performance of the hotels and the scores and reviews obtained. The research suggests the need to take into account and correctly manage reviews as well as the quality described and perceived through the scores awarded in them.

Among the many review websites in existence, Booking.com stands out. In July 2016, it operated in 224 countries and had 990,369 accommodation establishments worldwide and 98,780,000 verified reviews. A study by Sparks and Browning (2011) explored four factors considered to be key when influencing consumers' perception of truthfulness when assessing reviews of establishments on Booking.com, as well as the subsequent choices they make. An experimental design was used to investigate four independent variables: the aim of the comment or review (personal or professional); the overall balance of opinions (positive or negative); the formulation of opinions (whether negative or positive comments come first); and numerical score accompanying the text.

The results of the study indicated that consumers are more influenced by early negative information, especially when the overall set of comments is negative. However, positively framed information accompanied by numerical scores generates confidence in the consumer and influences intention to book. The results suggest that consumers tend to trust comments that are clearly worded and easy to process. Comments that focus on interpersonal customer service also generate high attributions of truthfulness.

After analyzing the results of the aforementioned studies, the authors concluded that more and more users trust opinions generated on the Net compared with other sources of information when deciding on their travel option (Sparks \& Browning, 2011).

\subsection{Citizen Journalism. A Social Loudspeaker for Complaints Managed by Users}

Processes such as digitization and the appearance of the Internet are the main factors that have revolutionized communication. The new formats present special and particular characteristics at narrative of discourse level. (Seisdedos et al., 2015).

Citizens have the fundamental right to receive information and express themselves. In the current media landscape, there is a certain information overload due to the sheer number of media outlets, and although it should be guaranteed that their content is of public interest and the information they disseminate is true, this is not always the case. The rights of citizens must be guaranteed as, despite the volume of messages they receive, they may be uninformed or receive contaminated information. It is necessary to guarantee the right ethical attitudes of communication professionals so that they work with the right goals in mind (Alonso González, 2015).

According to Bowman and Willis (2003), citizen journalism is considered to be that which takes an active role in the process of collecting, analyzing and disseminating information in the community, making contact with its needs. 
The mass media should be the real power behind the voice of the people. In some authoritarian and dictatorial countries, however, the State uses the mass media to its own ends. In other countries, despite being democratic, there are also abuses and errors in the handling of information to ensure power is exercised through control.

In this context, public opinion, an indispensable element of political and social pluralism, has found a new means of expression in citizen journalism (Pavlik, 2005).

The birth of social networks and citizen journalism represents the emergence of a fifth power that allows citizens to denounce media control by the financial giants and ensure that the information that reaches us is at least contrasted and refuted. Receivers have become specialized and demanding issuers with a voice, who have the ability to choose and participate in a different way to that traditionally allowed them (Carballido, 2008).

Furthermore, faced with this new media landscape, the genres representative of quality journalism, such as reports, chronicles or analyses, are threatened due to their making production routines more expensive and slower, while readers increasingly want the greater speed, interactivity, emotionality, and hypertextual superficiality of online journalism (Parratt, 2012).

One of the ways to develop new journalistic products for the Internet is using different social networks as a platform for publishing the contents of citizen journalism. Furthermore, in this environment, formats such as blogs or video blogs have become widespread with content generated exclusively by users, including the magazine "Qué!", the first Spanish medium to be produced by its own readers (Ayerdi, 2005).

Sometimes it is also referred to as social journalism, when it assumes responsibility, reflection and a search for solutions in the social sphere. According to Merritt (1998), who coined the term, "the contemporary press needs to be able to transcend the limited mission of telling the news, to achieve a broader mission, to help public life function correctly and to act based on this imperative".

According to Meso (2005): "Citizen journalism is that which allows the active participation of social actors in all the processing of information of public interest. Therefore, its essential characteristics are forming public opinion through the creation of deliberative audiences and promoting citizen participation."

\subsection{Collaborative Economy. Disruptive Economic Models Based on Sharing over the Internet}

According to Hadad Hadad and Valdés Llanes (2010), economic and financial crises are increasingly more frequent, profound and global. At the same time, economic slowdowns have an acute impact on the disadvantaged classes. This situation accelerates the appearance of alternative economic models for the production and commercialization of goods. In this environment, the collaborative economy represents a significant change from the capitalist model, since it is founded on a market based around collaboration and the exchange of goods and services between individuals.

According to Rosa (2014), disruptive models, and especially technological ones, are generating significant changes in markets and interpersonal relationships. In addition, this author emphasizes that civic technologies generated via the collaborative model allow for a more in-depth understanding of citizen participation mechanisms that contribute solutions to common problems characteristic of governance. They provide a basis for the opportunities generated by movements such as free software, open source, common creative licenses or open data, and are characterized by their enormous potential growth, which has a significant economic, environmental and social impact. Platforms are created for: the rental of products between private individuals - cars, caravans, vans, boats and homes; booking office and warehouse space for work purposes; sharing taxis between individuals; formalizing loans between individuals; putting teachers and students in contact for online courses, etc.

Contrasting with the advantages of the collaborative model, Pascual (2015) analyzes "some of the innumerable and important legal problems posed by these systems, taking as an illustrative example one of the sectors that has generated the most controversy in this regard: that of the taxi". This means of transport has been shown to suffer from disproportionately limiting regulations compared to others, a variable that has probably accelerated the rise of the collaborative economy in this sector in a way that raises relevant legal dilemmas. Furthermore, there has been an emergence of social and business movements contrary to the development of collaborative economies, including taxi drivers against Uber, professional drivers against Blablacar and the hotel industry against Airbnb or HomeAway. The author points out the need to establish a specific legal system that contemplates optimal limitations for guaranteeing the security and quality of services rendered while at the same time protecting the legitimate development of other economic activities. 


\section{Results}

\subsection{Ethical Principles. Self-regulation for New Formats and New Products}

The Internet poses a new scenario for communication, in which companies can choose from a wide range of digital devices to provide content to reach the user anywhere and at any time. The use, consumption and production of information have been transformed. In transmedia production, new guidelines for multi-platform regulation and multimedia recommendations are also required as consumers go to playing an active and key role in the design and architecture of new platforms. In these new communicative narratives, the public must act with ethical principles as they participate actively in the production and consumption of audiovisual content over the Net. It is important to educate new generations with the skills to differentiate reality from fiction (Jenkins, 2009).

In order to assess what society thinks about certain content broadcast in the media, a series of concepts such as audiences, critics, opinion polls, television viewers' associations and information and communication councils are used. Legal regulations are required that guarantee certain fundamental principles in any media and transmedia content broadcast (Van Dijk, 2016).

According to Kolbitsch and Maurer (2006), the information that is emitted or published on a medium must be truthful, rigorous, impartial, and respect human rights. It is necessary to act with responsibility and rigor when obtaining information in the case of information or opinions with content that may lead to discrimination, avoiding expressions or witnesses that may be offensive or harmful. A necessary but not sufficient condition for information to be more objective and fair is that it be complete, in the sense that it include all relevant points of view and also maintain a reasonable balance between all parties in the conflict, a fact that guarantees greater objectivity.

According to Kramers, Höjer, Lövehagen, and Wangel (2013), the principles of the deontological code of journalism are applicable to the new realities of communication. Therefore, information should be presented in accordance with regulatory mechanisms, respecting the principle of impartiality and neutrality. It must be narrated with precision and accuracy, in context and in depth. If there are contradictory sources on the issue, the different versions should be presented. Information needs to be contrasted in order to ensure it is not false or misleading. At the same time, it must be taken into account that certain aspects are emphasized depending on the chosen frame, shot, and camera movement in the recording, etc. Another aspect to take into account is the position of the camera with respect to the object. Equally, special care must be taken in selecting and arranging the image and sound, since editing and staging are a key phase in the development of the audiovisual product for it to be faithful, as a whole, to the truth.

In light of the deontological problems constantly posed in social media, self-regulation is necessary to guarantee that the principles of truth, freedom, justice and responsibility are observed. In line with this, a systematic study of cases published on social networks has revealed best practices and negative aspects to be improved. The data observed allow us to list a guide of 15 ethical principles to be used in the sphere of digital media (Bowen, 2013).

Furthermore, the use of audiovisual elements on social networks should give greater consistency to information, and in no case contribute to sensationalization per se. Obviously, the use of fictitious or archive images to exemplify or reconstruct facts must be made explicit.

The digital revolution has crossed the frontiers of traditional forms and genres of communication. In this environment, another important aspect when correctly presenting information is choosing the appropriate journalistic genre. According to Parratt (2012), in current times the traditionally used classificatory theory of journalistic genres "is insufficient to accommodate the enormous number of variants that continually appear as a result of the evolution of the journalistic profession, heading towards the proliferation of mixed genres and influenced by audiovisual media." While it is true that this classification must evolve and be completed in accordance with the times, it is no less true that classifying a publication as news, report, chronicle, commentary, criticism, etc. greatly facilitates its reception by the reader. It is important to continue developing ethical principles of self-regulation to be able to find one's way on the Net. 
Table 1. 15 Ethical guidelines for social media use

Adapted from Bowen (2013)

\begin{tabular}{|c|c|}
\hline Guideline & Justification and application \\
\hline $\begin{array}{l}\text { \#Analysis } \\
\text { Analyze the situation }\end{array}$ & $\begin{array}{l}\text { Examine messages rationally from all points of view. How could it be } \\
\text { misinterpreted? }\end{array}$ \\
\hline $\begin{array}{l}\text { \#Good } \\
\text { Encourage the good }\end{array}$ & Does your message help build connectivity, commitment, and community? \\
\hline $\begin{array}{l}\text { \#Clarity } \\
\text { Emphasize clarity }\end{array}$ & $\begin{array}{l}\text { Special attention must be paid to stating the source of the information and } \\
\text { sponsorship, if it exists. }\end{array}$ \\
\hline $\begin{array}{l}\text { \#Consistency } \\
\text { Consistency generates trust }\end{array}$ & $\begin{array}{l}\text { Consistency allows audiences to better know and understand you, and you } \\
\text { can identify their expectations. }\end{array}$ \\
\hline $\begin{array}{l}\text { \#Dignity } \\
\text { Maintain dignity and respect }\end{array}$ & $\begin{array}{l}\text { Ensure that the publication maintains dignity and respect towards the publics } \\
\text { involved. }\end{array}$ \\
\hline $\begin{array}{l}\text { \#Deceit } \\
\text { Avoid deceit }\end{array}$ & $\begin{array}{l}\text { If the news item may be misleading, even if only possibly, simply do not } \\
\text { publish it. }\end{array}$ \\
\hline $\begin{array}{l}\text { \#Identification } \\
\text { Identify clearly }\end{array}$ & $\begin{array}{l}\text { Information and personal opinion should be clearly differentiated for } \\
\text { publications representing an organization. }\end{array}$ \\
\hline $\begin{array}{l}\text { \#Intention } \\
\text { Examine intention }\end{array}$ & Did you take your decision only out of goodwill? \\
\hline $\begin{array}{l}\text { \#Prudence } \\
\text { Be fair and prudent }\end{array}$ & Consider fairness, justice and citizens' right to be informed. \\
\hline $\begin{array}{l}\text { \#Responsibility } \\
\text { Establish your responsibility }\end{array}$ & Is your publication fulfilling its responsibility to do what is right? \\
\hline $\begin{array}{l}\text { \#Revelation } \\
\text { Reveal }\end{array}$ & $\begin{array}{l}\text { Be transparent with the date the message was created and the date of the } \\
\text { events. }\end{array}$ \\
\hline $\begin{array}{l}\text { \#Reversibility } \\
\text { Is it reversible? }\end{array}$ & $\begin{array}{l}\text { How would you feel if you were at the receiving end of the message? Is it still } \\
\text { ethical then? }\end{array}$ \\
\hline $\begin{array}{l}\text { \#Secret } \\
\text { Avoid publishing secrets }\end{array}$ & These could be trade secrets or other secrets protected by law. \\
\hline $\begin{array}{l}\text { \#Transparency } \\
\text { Be transparent }\end{array}$ & Clearly identify who finances the publication. \\
\hline $\begin{array}{l}\text { \#Verification } \\
\text { Verify sources and data }\end{array}$ & edible, do \\
\hline
\end{tabular}

\section{Discussion}

Our analysis of recent research in the current media landscape has shown that large financial groups exert an enormous influence on the media. Economic globalization has generated large media groups that subordinate the political power of states to the interests of the financial market.

To ensure that the media are plural, can freely emit content and are representative of modern democracy, the interventionism of the big financial giants must be prevented by introducing regulation and self-regulation mechanisms, which are the only guarantee to preserve transparency and defend open societies characterized by communication professionals that display ethical attitudes.

Information professionals are required to ensure the correct management of user generated content; professionals who act with professional rigor and are not swayed by economic criteria and interests related only to audiences.

Given this situation, in first place social networks have become a tool at the service of citizens in the face of media globalization; a counter-power to the large communication groups, and an opportunity for societies to express themselves and make themselves freely heard.

Secondly, in an environment dominated by global economic groups, review websites force companies to optimize their services and improve their relationship with the customer, placing customers' comments at the epicenter of this dynamic.

In third place, citizen journalism represents a fifth power for citizens that guarantees them the right to expression and to receive correct and truthful information, uncontaminated by economic interests.

Fourthly, the collaborative economy is a radical change with respect to the current economic model, since it places collaboration and exchange before possession thanks to the Net.

Therefore, faced with these new challenges, it is essential to continue developing ethical self-regulation principles to guarantee the veracity and rigor of new forms of communication.

At the same time, it is essential to create impartial, credible and independent bodies that help amplify the voice of citizens in the face of corporate and media globalization. 
Vusiness [from business, but with "V" for values] was born with this objective in mind. It is an observatory that promotes open, democratic, sustainable and inclusive companies that are to inspire the future. The observatory was created out of the Arpa research group (Audiovisual Screen Reception Analysis Group), which belongs to the University of Girona's Philology and Communication Department. Vusiness represents a proposal for companies to move towards a new business ethics and policy.

This study is considered preliminary and has the aim of describing an approach to the revolution and opportunity the Internet represents for society in the face of economic globalization.

The results of this bibliographical review highlight the enormous challenge involved in continuing to move towards new integrative models capable of amplifying the voice of citizens in an ethically regulated way, particularly in an environment changing so rapidly due to the Internet.

The literature in the field of media globalization and new forms of communication in society via the Internet is undergoing significant growth due to it being an emerging field. Even so, descriptive and experimental studies capable of defining new forms of balanced and positive communication are required, to guarantee both the rights of societies to express their opinions and criticisms and of companies to fulfill their legitimate objectives.

In addition, it is important to generate informative and formative material to educate citizens on the principles of ethical self-regulation.

Last but not least, in line with the WAI (Web Accessibility Initiative), the media must make an effort to guarantee universal access to all websites for people with disabilities, to encourage their participation and guarantee a fully inclusive society.

The results and conclusions described in this preliminary review require thorough and interdisciplinary research.

\section{References}

Aced Toledano, C., \& Lalueza Bosch, F. (2016). ¿ Qué contenidos publican las empresas en los medios sociales? Análisis crítico del discurso de las compañías del IBEX 35 y del Fortune 500 en blogs corporativos, Facebook y Twitter/What Content are Companies Publishing on Social Media? Critical Discours. Revista Internacional de Relaciones Públicas, 6(11), 135-154.

Alonso González, M. (2015). Las redes sociales como canal de comunicación de las marcas de moda españolas. El caso de Zara, Mango y El Corte Inglés/Social networks as communication channels of Spanish fashion brands: Zara, Mango and El Corte Inglés. index. comunicación, 5(1), 77-105.

Ayerdi, K. M. (2005). Periodismo ciudadano: voces paralelas a la profesión periodística. Chasqui. Revista Latinoamericana de Comunicación, 90, 4-13.

Bowen, S. A. (2013). Using classic social media cases to distill ethical guidelines for digital engagement. Journal of Mass Media Ethics, 28(2), 119-133. https://doi.org/10.1080/08900523.2013.793523

Bowman, S., \& Willis, C. (2003). We media. How audiences are shaping the future of news and information.

Campos, F. (2008). Las redes sociales trastocan los modelos de los medios de comunicación tradicionales.

Cánovas, J. P. M., García, J. J. B., \& María-Dolores, S. M. M. (2015). El mito de las opiniones manipuladas en Tripadvisor. Papers de Turisme, 58, 1-17.

Carballido, J. R. S. (2008). Perspectivas de la información en Internet: ciberdemocracia, redes sociales y web semántica. Zer: Revista de estudios de comunicación = Komunikazio ikasketen aldizkaria, 25, 61-81.

Chua, A. Y., \& Banerjee, S. (2013a). Customer knowledge management via social media: the case of Starbucks. Journal of Knowledge Management, 17(2), 237-249. https://doi.org/10.1108/13673271311315196

Chua, A. Y., \& Banerjee, S. (2013b). Reliability of reviews on the Internet: The case of Tripadvisor. Paper presented at the Proceedings of the World Congress on Engineering and Computer Science.

Dasilva, J. P. (2013). Las empresas en Facebook y Twitter. Situación actual y estrategias comunicativas. https://doi.org/10.4185/RLCS-2013-996

García-Galera, M., del Hoyo-Hurtado, M., \& Fernández-Muñoz, C. (2014). Jóvenes comprometidos en la Red: el papel de las redes sociales en la participación social activa. Comunicar: Revista Científica de Comunicación y Educación, 22(43), 35-43. https://doi.org/10.3916/C43-2014-03

Hadad Hadad, J. L., \& Valdés Llanes, E. (2010). La protección social en salud como enfrentamiento a una crisis económica. Revista Cubana de Salud Pública, 36(3), 235-248. https://doi.org/10.1590/S0864-34662010000300008 
Herman, E. S., \& Chomsky, N. (2010). Manufacturing consent: The political economy of the mass media: Random House.

Horner, S., \& Swarbrooke, J. (2016). Consumer behaviour in tourism: Routledge.

Islas, O., Arribas, A., Piscitelli, A., Adaime, I., \& Binder, I. (2010). Comprender las redes sociales como ambientes mediáticos. A. Piscitelli, I. Adaime e I. Binder (Comps.), El proyecto facebook y la posuniversidad. Sistemas operativos sociles y entornos abiertos de aprendizaje, 147-161.

ITB, B. (2014). ITB world travel trends report 2014/2015. Berlin. Messe Berlin GmbH.

Jenkins, H. (2009). Transmedia storytelling. 1, 56.

Kolbitsch, J., \& Maurer, H. A. (2006). The Transformation of the Web: How Emerging Communities Shape the Information we Consume. J. UCS, 12(2), 187-213.

Kramers, A., Höjer, M., Lövehagen, N., \& Wangel, J. (2013). ICT for Sustainable Cities: How ICT can support an environmentally sustainable development in cities. Paper presented at the ICT4S 2013: Proceedings of the First International Conference on Information and Communication Technologies for Sustainability, ETH Zurich.

Madge, C., Meek, J., Wellens, J., \& Hooley, T. (2009). Facebook, social integration and informal learning at university: 'It is more for socialising and talking to friends about work than for actually doing work'. Learning, Media and Technology, 34(2), 141-155. https://doi.org/10.1080/17439880902923606

Manfredi, J. L. (2004). Servicio público y calidad en la televisión pública. Revista Andaluza de Administración Pública, 56, 275-297.

Merritt, D. (1998). Public journalism and public life: Why telling the news is not enough.

Meso, K. (2005). El desafío profesional del periodista digital ante las posibilidades de Internet. Paper presented at the VI Congreso Nacional de Periodismo Digital.

Parratt, S. F. (2012). El debate en torno a los géneros periodísticos en la prensa: nuevas propuestas de clasificación. Zer-Revista de Estudios de Comunicación, 6(11).

Pascual, G. D. (2015). La regulación de la economía colaborativa (El caso «Uber contra el taxi»). CEFLegal: revista práctica de derecho. Comentarios y casos prácticos, 175, 61-104.

Pavlik, J. V. (2005). El periodismo y los nuevos medios de comunicación.

Ramonet, I. (2016). Guerras, memorias, justicia. Le Monde diplomatique en español, 245, 1-2.

Rosa, R. M. (2014). Tecnologías cívicas y participación ciudadana. Revista de Estudios de Juventud, 105, 53-70.

Seisdedos, G., Richart, B., Gallego, G., Paz, J. D., Esponera, J., \& Kolotouchkina, O. (2015). Smart Cities: La transformación digital de las ciudades Centro de Innovación del Sector Público de PwC e IE Business School.

Sparks, B. A., \& Browning, V. (2011). The impact of online reviews on hotel booking intentions and perception of trust. Tourism Management, 32(6), 1310-1323. https://doi.org/10.1016/j.tourman.2010.12.011

Tuominen, P. (2011). The influence of TripAdvisor consumer-generated travel reviews on hotel performance.

Van Dijk, T. A. (2016). Estudios Críticos del Discurso: Un enfoque sociocognitivo. Discurso \& Sociedad, 1, 137-162.

Vivo, J. M. N. (2010). Redes sociales como paradigma periodístico. Medios españoles en Facebook/Social networks as journalistic paradigm. Spanish media on Facebook. Revista latina de comunicación social, 65, 176. https://doi.org/10.4185/RLCS-65-2010-891-176-186-EN

\section{Copyrights}

Copyright for this article is retained by the author(s), with first publication rights granted to the journal.

This is an open-access article distributed under the terms and conditions of the Creative Commons Attribution license (http://creativecommons.org/licenses/by/4.0/). 